\title{
SEMI-STRONG INFORMATION EFFICIENCY \\ OF THE POLISH STOCK EXCHANGE MARKET \\ IN VARIOUS MARKET SITUATIONS
}

\section{Marcin Kalinowski}

Gdansk School of Banking

Abstract: The aim of this paper is determining the level of information efficiency at the semi-strong stage of the largest Polish companies on the stock market (covered by WIG20 index) in different market conditions.

To achieve this aim the author decided to create a graphic representation of semistrong information efficiency. In the paper the author analyses the Polish stock market indicators in the years 2005-2008.

The study examine a linear relationship between $P / E, P / B V$ ratio and the rate of return. As the indicator in analysis is used direction of slope of the regression line. In this research is analyzed the character and size of regression coefficient.

Keywords: Market Efficiency, Capital Market, Capital Investment

\section{Introduction}

The foundations of the capital market theory were created by Luis Bahelier at the beginning of the 20-th century [1]. He claims that pricing is random on the market so the probability of achieving higher than average return on investment on the capital market cannot be increased. Business literature of the 1960s deals with the problem of information in investment decision making processes. This approach is strongly stressed in the works of P. Cootner [2].

The contemporary theory of market efficiency was also presented in the works of P. Sammelson who demonstrated in 1965 that price changes are unpredictable if they are correctly anticipated [3].

The present day knowledge of market efficiency is based on the definitions of E. Fama who demonstrated that the efficient market is one in which prices always reflect available information. The analysis of the pricing process on the capital market is an issue which has not been sufficiently explained in business literature. The reality of the capital market differs considerably from the reality of the 1970s. The development of modern investments tools changed the approach to the capital investment process and risk management.

The classic economic theory says that investors behave in a rational way. The progress in behavioral finance changed the classic view on investment decision making. The Nobel Prize in economics awarded to Daniel Kahnemann proves that there is a need for research in investment decisions [5]. Analysing the level of efficiency may be particulary important in the period of economic crises on the financial markets. 
During a crisis a higher price changeability is noticeable on the financial market. Capital investment on the stock market is a problem concerning more and more people in this context. An attempt to determine effective decision making methods is an issue for both physical and legal persons including instructions managing investment portfolios.

The aim of this paper is determining the level of information efficiency at the semistrong stage of the largest Polish companies on the stock market (covered by WIG20 index) in different market conditions.

To achieve this aim the author decided to create a graphic representation of semistrong information efficiency. In the next section of the paper the author analyses the Polish stock market from the point of view efficiency in the years 2005-2008.

The hypotheses tested by the author:

1) The efficiency of the Polish stock market is dependent on the condition of the financial market.

2) The Polish stock market is efficient in the time of crises, which means that information about companies is reflected in their share prices.

\section{The hypothesis of capital market efficiency (weak, semi-strong, strong)}

It is becoming more problematic to explain price changes on the stock market analyzing rational behavior of investors. Investment decisions are often disconnected from the financial analysis of a company.

Financial market efficiency is an element of considerations concerning capital investments. Satisfactory ROI (return on investment) is correlated with market efficiency. It is therefore important to conduct research on stock market efficiency and compare results. It is the basis for taking effective investment decisions on different markets.

Theoretical market efficiency foundations are based on the following assumptions [8]:

- investors take rational decisions and correctly price financial assets,

- irrational investors behave chaotically and their actions have no impact on the market because they are uncoordinated,

- irrational investors who incorrectly price the shares are eliminated from the market by arbitrageurs.

Business literature lists 3 stages of capital market efficiency. They are as follows: allocation efficiency, transactional efficiency and information efficiency. Allocation efficiency is about capital provision to the sectors or companies in which capital will be used most effectively. Transactional efficiency takes place in the situation when middlemen (intermediaries) working on the market compete with one another reducing transactional costs and speeding up transactions. Information efficiency is based on quick current information transfer to all players on the market with the result of an immediate effect on share prices [7]. 
E. Fama is the author of the information efficiency [4]. According to him the effective capital market is the one in which the prices of financial instruments always fully reflect all available information. It is necessary to systemize information coming to the market because of its amount and categories. The categories are as follows:

- information about past financial assets prices,

- public information which may have an impact on financial assets pricing,

- confidential information.

In connection with this division of information entering the market Fama proposed distinguishing three types of information efficiency: weak, semi- strong, strong.

In the weak type of information efficiency share prices reflect all the information included in the prices of a particular share in the past. In case of positive tests results of this efficiency type, the prices are characterized by random selection. In this situation it is impossible to achieve higher then average return on investment by analyzing past prices. Technical analysis tools are used to test weak information efficiency of the capital market. This analysis uses past trends and tendencies for determining future prices.

In semi- strong type of capital market efficiency the prices of equities reflect all published information related to them. Fundamental analysis ratios are used to test this form of market efficiency. They indicate the impact of generally available information on share prices. All data concerning a company should be immediately included in share prices. There is no possibility of achieving higher then average return on investment applying the fundamental analysis in investment decision making.

Strong efficiency is the third type of capital market information efficiency. In this case it is assumed that public and confidential information is immediately becoming an element of share prices and may exert influence on a company's market value.

The division into three types of capital market information efficiency has proved to be insufficient. Therefore, in 1983 Simon Keane proposed a further sub-division of each efficiency form into three sub-types: perfect efficiency, imperfect efficiency and inefficiency (non-existent) [6]. In each type of information efficiency we can point out one of three subtypes.

\section{Semi-strong efficiency tests on the Polish stock market companies (based on WIG20*)}

A market research has been conducted with the purpose of testing semi- strong efficiency on the Polish stock market. Twenty biggest companies functioning on the Polish market have been chosen for tests (WIG20 companies). The testing concerned two fundamental analysis ratios - P/E (Price/Equity) and P/BV (Price/Book Value) referring to annual return on investment on the company stock. The data describe the period from 2005 till 2008.

\footnotetext{
* Warsaw Stock Exchange index of 20 biggest corporations
} 
The proposed solution is a novel form of analysing and testing semi- strong efficiency of companies. It has been assumed that if in the to period P/E and P/BV ratios are on a high level we may conclude that the shares of a tested company are overrated in the next period of time return of investment in the group of tested companies should be below average.

If we agree that our assumption is valid and transfer test results onto the point Fig. where the horizontal axis is annual ROI and the vertical axis is P/E and P/BV at the beginning of the tested period, the angle of the average trend line based on the market points will determine the degree of semi- strong efficiency in the tested companies. The subsequent Fig.s show test results for particular years between 2005 and 2008.

The study will examine a linear relationship between P/E, P/BV ratio and the rate of return. As the indicator in analysis will be used direction of slope of the regression line. In this research will be analyzed the character and size of regression coefficient.

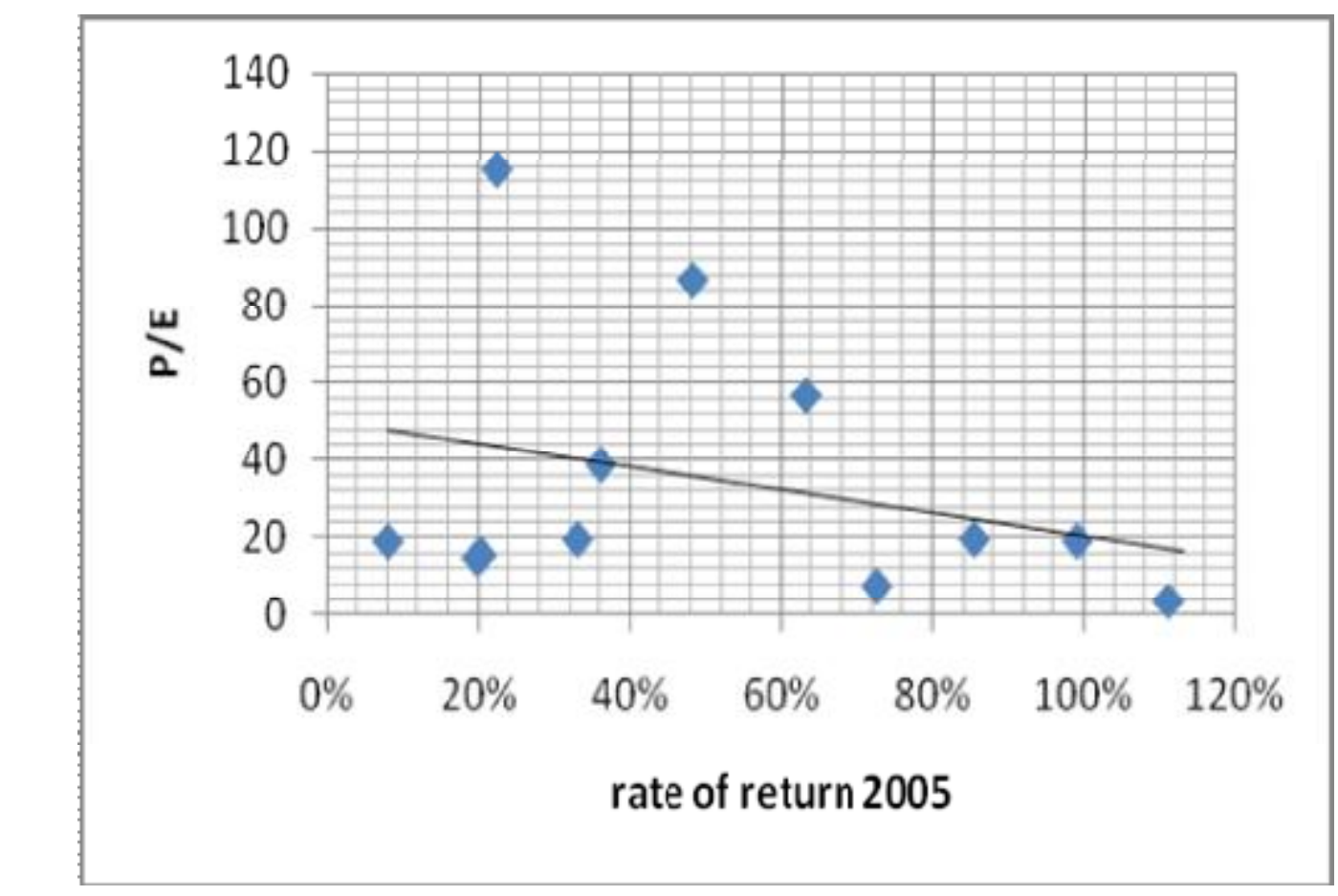

Fig. 1: Rate of return and P/E ratio of WIG20 companies scatter plot with regression line in 2005

Source: individual research based on Warsaw Stock Exchange data [9] 


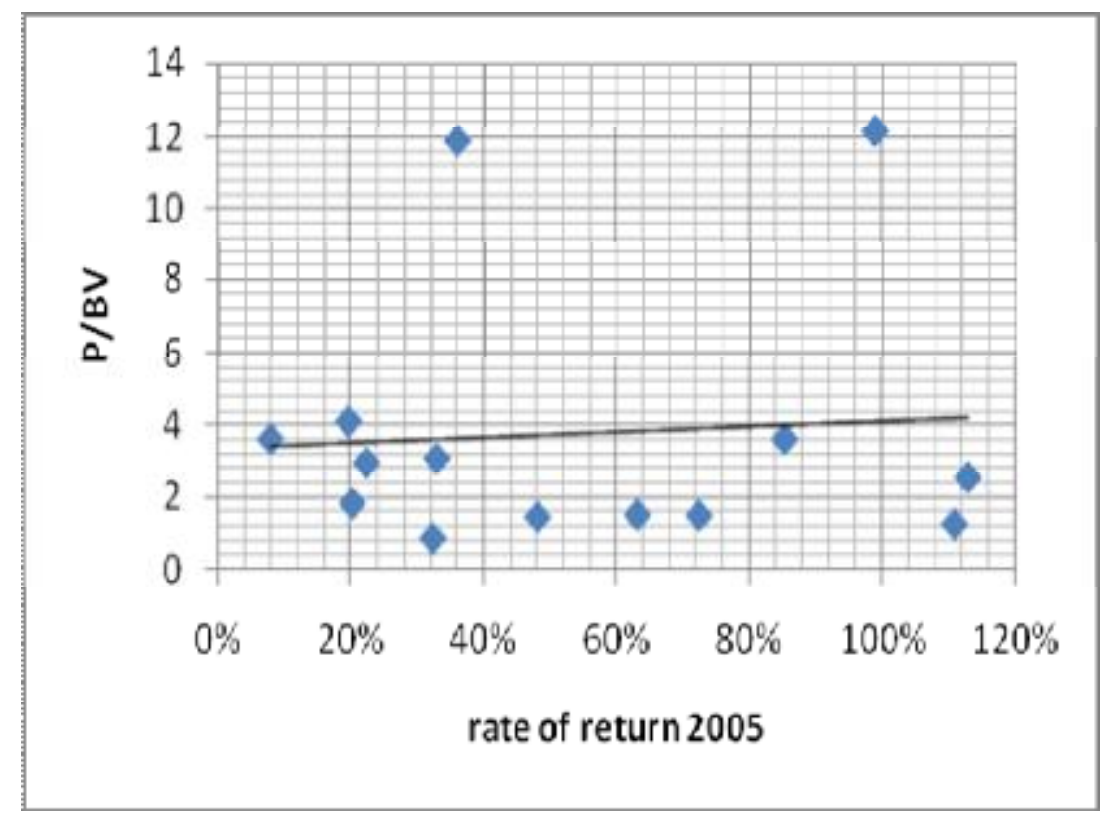

Fig. 2: Rate of return and P/BV ratio of WIG20 companies scatter plot with regression line in 2005

Source: individual research based on Warsaw Stock Exchange data [9]

The first Fig. shows ROI in relation to P/E ratio demonstrating market inefficiency in this period. Companies with a low P/E ratio had higher ROI than companies with a higher $\mathrm{P} / \mathrm{E}$ ratio.

Inefficiency in the same period is not confirmed by $\mathrm{P} / \mathrm{BV}$ ratio for the same companies (Fig. 2). The lines in the graphs demonstrate opposite tendencies. In this case, the author proposes the tested efficiency is neutral.

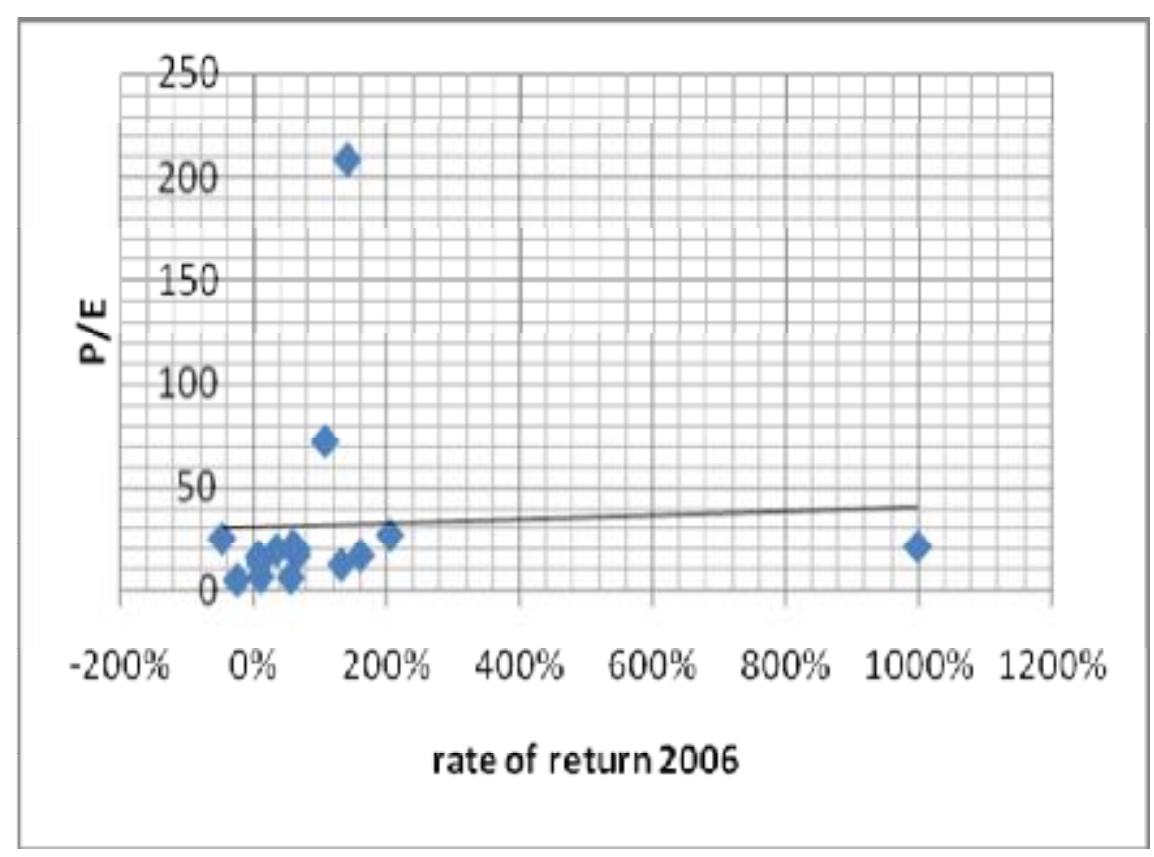

Fig. 3: Rate of return and P/E ratio of WIG20 companies scatter plot with regression line in 2006

Source: individual research based on Warsaw Stock Exchange data [9] 


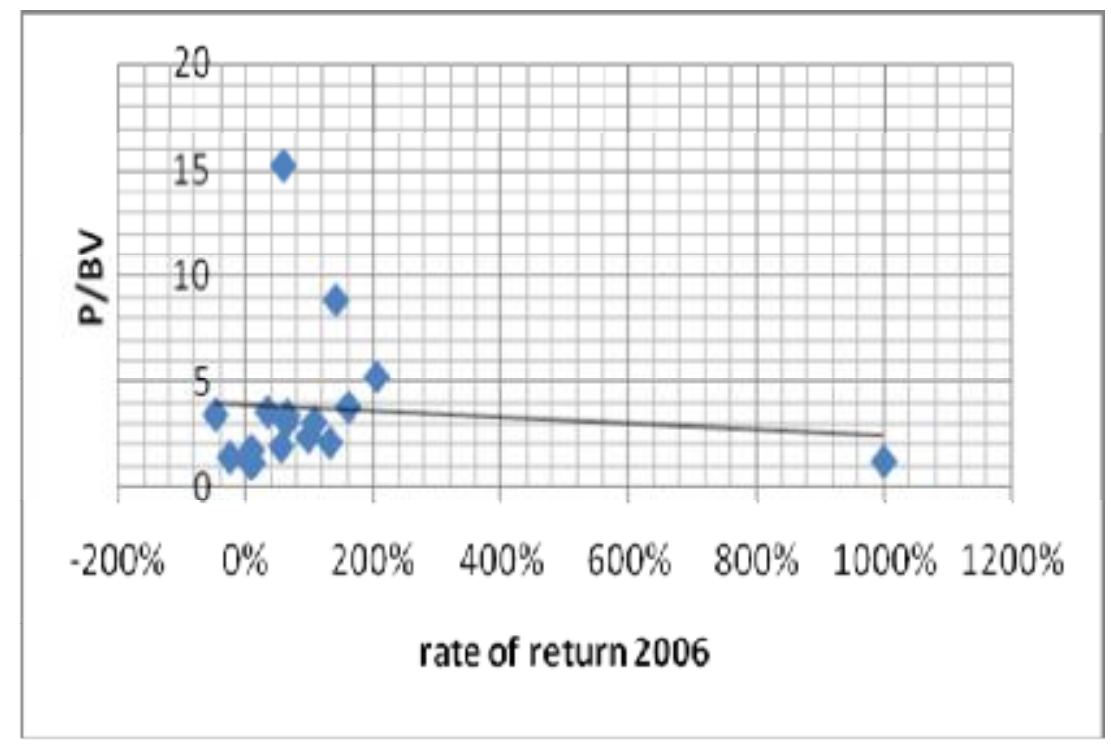

Fig. 4: Rate of return and P/BV ratio of WIG20 companies scatter plot with regression line in 2006

Source: individual research based on Warsaw Stock Exchange data [9]

The years 2005 and 2006 were quite similar. The trend lines of P/E and P/BV ratio in relation to the annual rate of return of WIG20 companies show opposite tendencies. Therefore, we can speak about neutrality of semi-strong efficiency in 2006. There is the outlier (the point which varies considerable from others) on Fig. 3 and 4. This data can affect on slope of regression line in year 2006 but it will stay in this research.

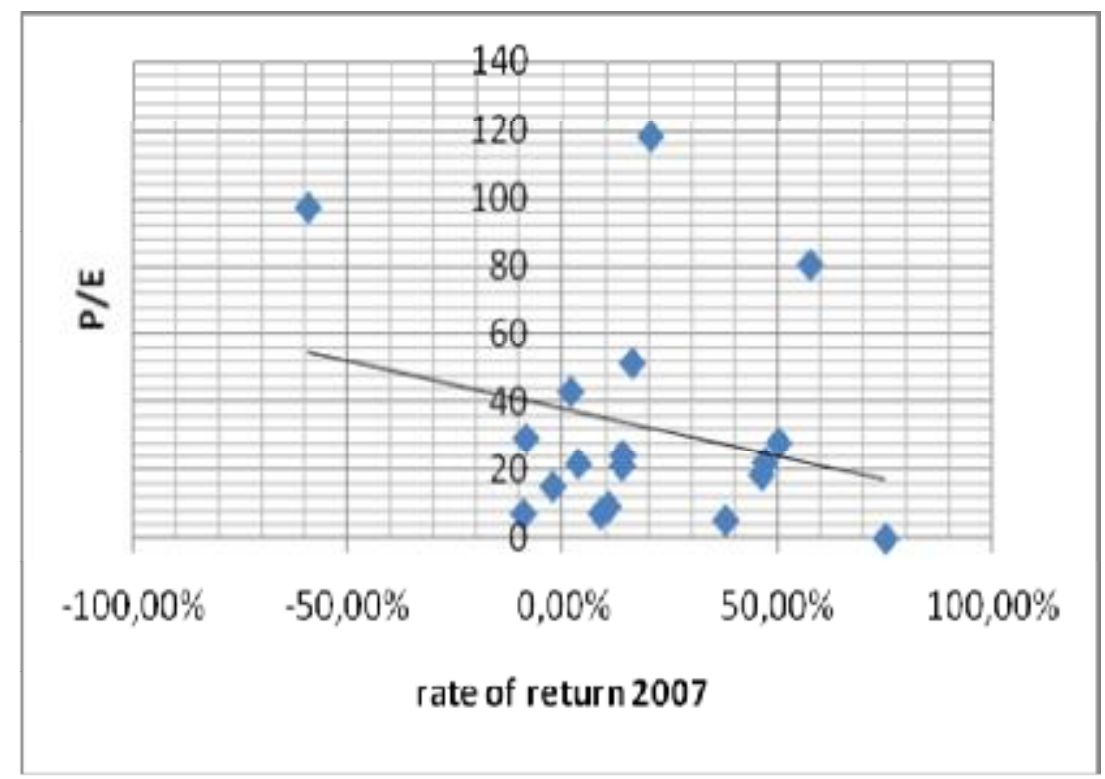

Fig. 5: Rate of return and P/E ratio of WIG20 companies scatter plot with regression line in 2007

Source: individual research based on Warsaw Stock Exchange data [9] 


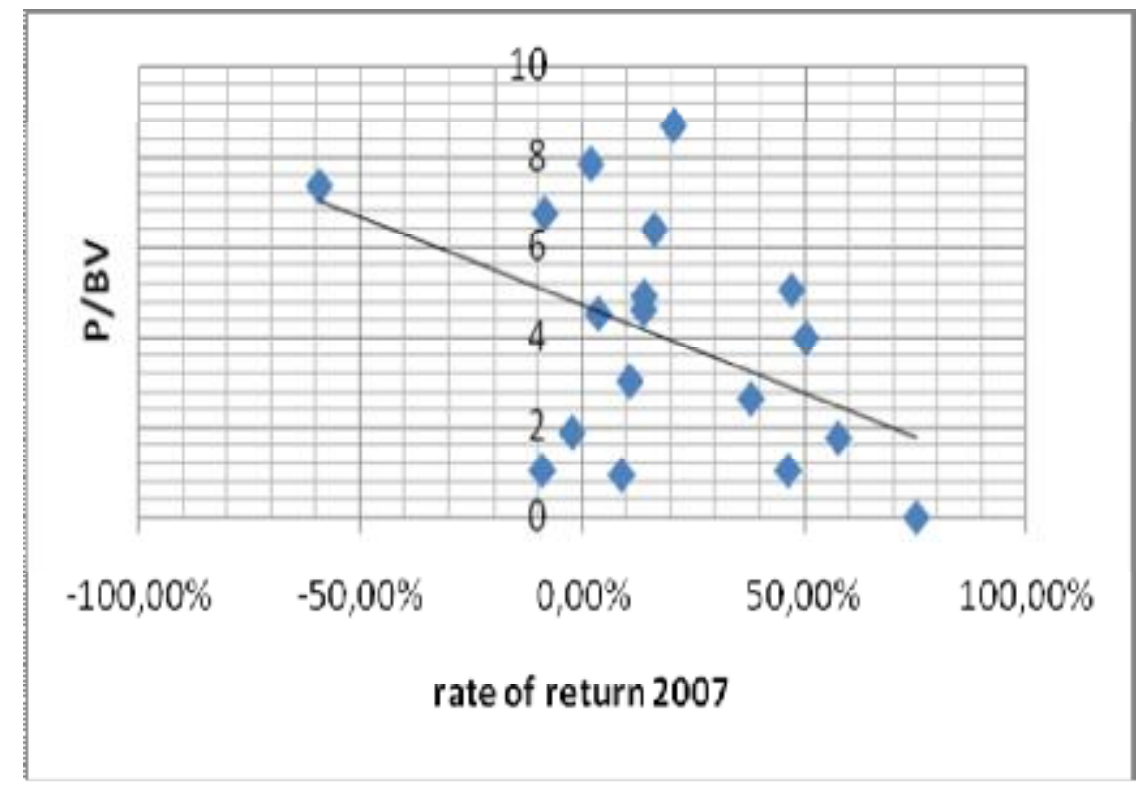

Fig. 6: Rate of return and P/BV ratio of WIG20 companies scatter plot with regression line in 2007

Source: individual research based on Warsaw Stock Exchange data [9]

The year 2007 marks the end of the continuing upword trend on the Polish stock market and is the beginning of a considerable downturn (Fig. 7). This situation is strongly related to global tendencies on financial markets. In this situation P/E and $\mathrm{P} / \mathrm{BV}$ ratios referring to the annual rate of return were comparable. The growth in the level of ratios on the tested sample was linked with the average annual rate of return. The fundamental analysis for predicting the rate of return of WIG20 companies could be applied for the tested period. This strategy would ensure above average rate of return on this market. This case illustrates information inefficiency of the tested market in 2007.

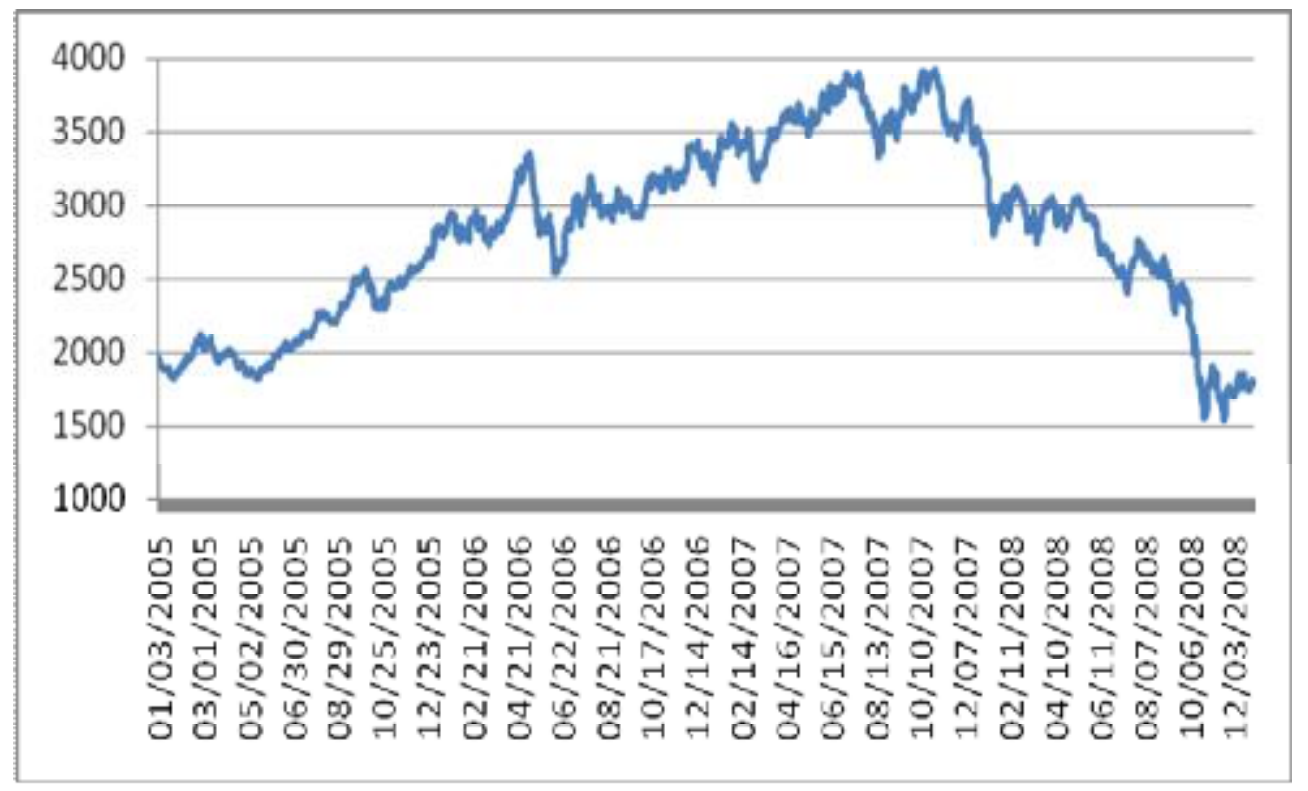

Fig. 7: WIG20 index between 2005 and 2008

Source: individual research based on Warsaw Stock Exchange data [9] 


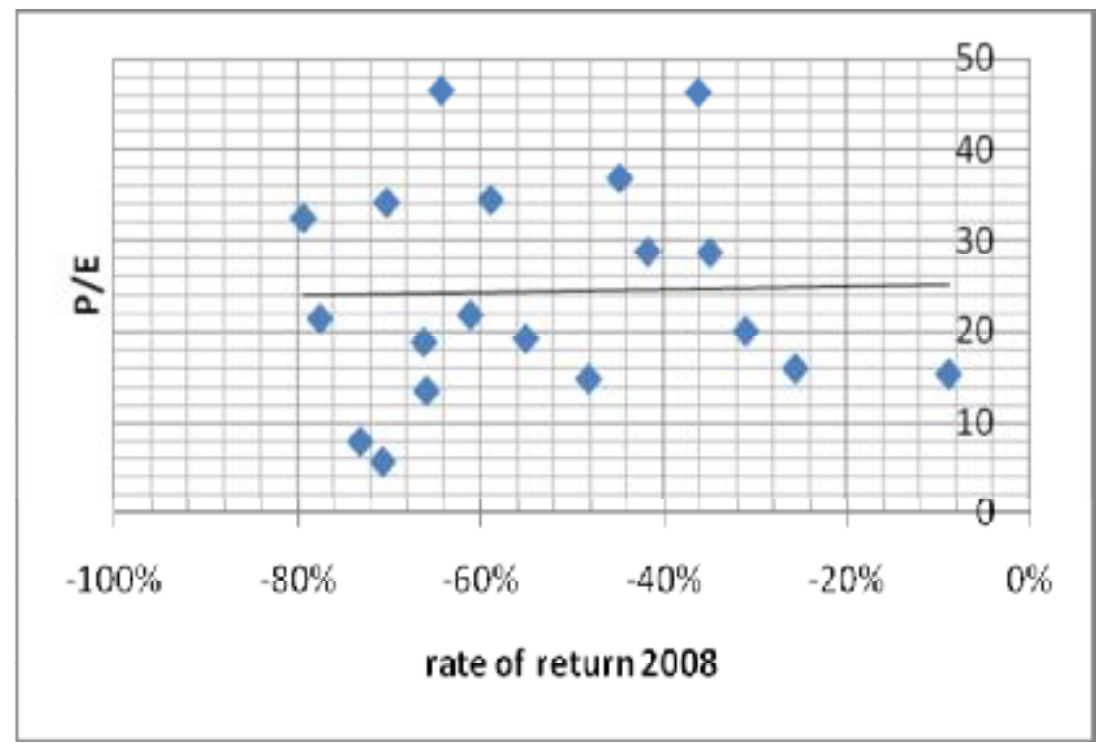

Fig. 8: Rate of return and P/E ratio of WIG20 companies scatter plot with regression line in 2008

Source: individual research based on Warsaw Stock Exchange data [9]

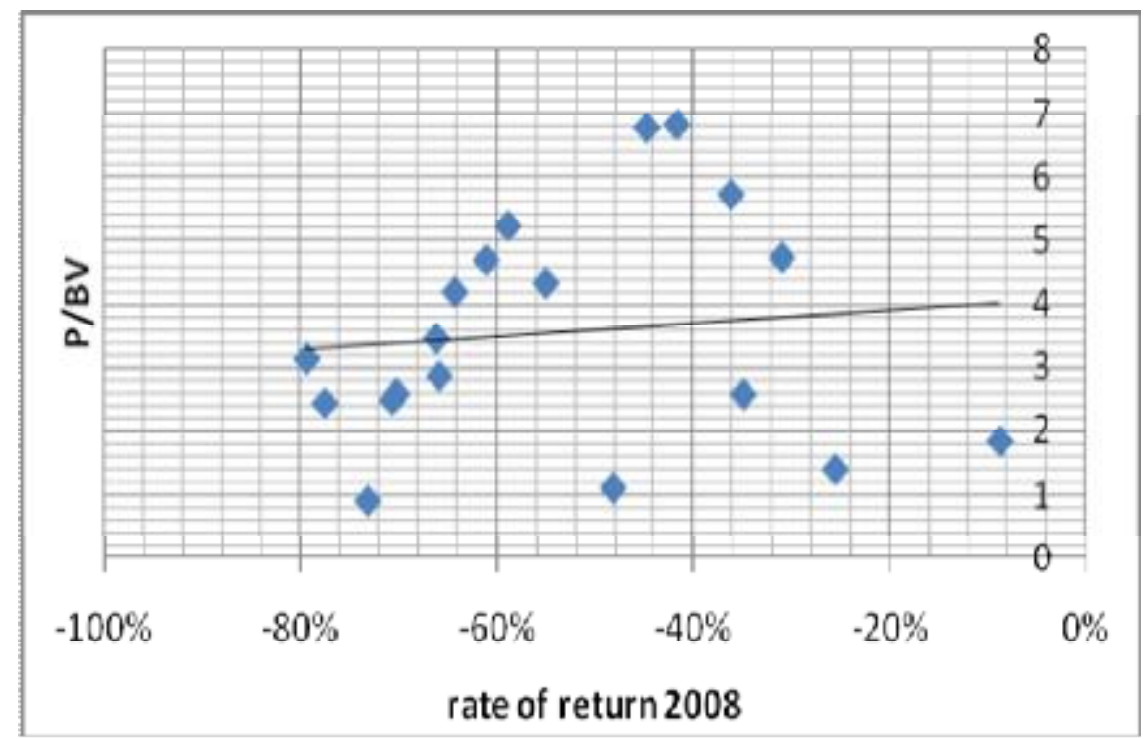

Fig. 9: Rate of return and P/BV ratio of WIG20 companies scatter plot with regression line in 2008

Source: individual research based on Warsaw Stock Exchange data [9]

The global financial crises of 2008 had a negative impact on the Polish stock market. Negative tendencies cost a fall in WIG20 index by $48 \%$. Taking into account the tested ratios of the fundamental analysis it is visible that the market was efficient. A growth in P/E and P/BV ratio levels in the tested sample resulted in a higher rate of return. On the basis of the tested sample it was impossible to make investment decisions leading to above average profits generated by tested companies. 


\section{Conclusions}

The conducted research demonstrates that there is a correlation between capital market prosperity and information efficiency on this market. The outcome of the research referring the level of fundamental analysis ratios P/E and P/BV to the rate of return in the following period prove that the situation on the capital market influences semi-strong information efficiency. The table below shows the complex results of the research.

Tab. 1: The results of the research on the correlation between rate of return and $P / E, P / B V$ ratios of WIG20 companies quoted on Warsaw Stock Exchange between 2005 and 2008

\begin{tabular}{|c|c|c|c|c|}
\hline Year & $\begin{array}{c}\text { WIG20 } \\
\text { (change in \%) }\end{array}$ & $\begin{array}{c}\text { Correlation } \\
(\text { P/E)/ROI }\end{array}$ & $\begin{array}{c}\text { Correlation } \\
(\text { P/BV } / \text { ROI }\end{array}$ & $\begin{array}{c}\text { Information } \\
\text { Efficiency }\end{array}$ \\
\hline $\mathbf{2 0 0 5}$ & $+35,42 \%$ & - & + & 0 \\
\hline $\mathbf{2 0 0 6}$ & $+23,75 \%$ & + & - & - \\
\hline $\mathbf{2 0 0 7}$ & $+5,19 \%$ & - & - & + \\
\hline $\mathbf{2 0 0 8}$ & $-48,21 \%$ & + & + & + \\
\hline
\end{tabular}

Source: individual research based on Warsaw Stock Exchange data [9]

After analyzing the largest Polish companies we may conclude that semi-strong information efficiency exists on the market with visible negative tendencies. In the periods of growth the fundamental analysis ratios are not sufficient to clearly determine the effectiveness of the tested market. The market is characterized by information inefficiency when market trends change (2007).

On the basis of the described test of semi-strong type of information efficiency of the Polish stock market we may conclude that its efficiency is dependent on the prosperity on financial market. This confirms the first research hypothesis of this paper. The analysis of the conducted research indicates that in times of crises the Polish stock market is efficient. The second hypothesis of the paper is confirmed by this.

The proposed method of information efficiency research on the capital market seems adequate and reliable. It is likely that the method of information efficiency research on the semi-strong type presented in the article is reliable and may be used on all capital markets. The clear and transparent presentation of test results may encourage investors all over the world to apply it. 


\section{References:}

[1] BAHELIER, L., Théorie de la spéculation, Gauthier-Villars, Paris, 1900.

[2] COOTNER, P., The random Character of Stock Market Prices. Cambridge, MA: The MIT Press, 1964.

[3] CZEKAJ, J., WOŚ, M., ŻARNOWSKI, J., Efektywność giełdowego rynku akcji w Polsce, PWN, Warszawa 2001. ISBN 83-01-13470-4.

[4] FAMA, E. F. Efficient Capital Markets: a Review of Theory and Empirical Work, Journal of Finance, May 1970, No. 25. ISSN 0022-1082.

[5] KAHNEMANN, D., TVERSKY, A., Prospect theory: An analysis of Decisions Under Risk. Econometrica, 47, march 1979. ISSN 0012-9682.

[6] KEANE, S., Stock market efficiency - theory, evidence, implications, PA Publishers, Oxford 1983.

[7] NOWAKOWSKI, J., BOROWSKI, K., Giełda Papierów Wartościowych w Warszawie na tle rynków Światowych, Studia i Prace Kolegium Zarzqdzania $i$ Finansów, nr 28, Szkoła Główna Handlowa, Warszawa 2002. ISSN 1234-8872.

[8] SHLEIFER, A., Inefficient Markets. An introduction to Behavioral Finance, Oxford University Press, 2000. ISBN 0-19829228-7.

[9] WSE Yearly Bulletin, Year 2004, 2005, 2006, 2007, 2008, Warsaw Stock Exchange http://www.gpw.pl/gpw.asp?cel=informacje gieldowe \&k=18\&i=/statystyki/roczn e\&sky=1.

\section{Contact address:}

Marcin Kalinowski PhD.

Gdansk School of Banking

E-mail: mkalinowski@wsb.gda.pl

Phone: (+48) 609880094 